\title{
AN ANALYSIS OF ECONOMIC ISSUES DURING FIRST AND SECOND WAVE OF COVID-19 PANDEMIC IN INDIA: A LITERATURE SURVEY
}

\author{
Manuranjan Gogoi ${ }^{1}$, Pranjal Protim Buragohain ${ }^{2}$, Purabi Gogoi ${ }^{3}$, Atanu Hazarika ${ }^{4}$ \\ ${ }^{1}$ Assistant Professor (Contract), Dept. of Economics, Madhabdev University, Narayanpur, \\ Lakhimpur, Assam, India-784164, Email: manuranjan7@gmail.com \\ ${ }^{2}$ Associate Professor, Dept. of Economics, Dibrugarh University, Dibrugarh, Assam, India- \\ 786004,Email: pranjalprotim@dibru.ac.in \\ ${ }^{3}$ Assistant Professor, Dept. of Economics, T.H.B. College, Jamugurihat, Sonitpur, Assam, India- \\ 784189, Email: purabigogoi936@gmail.com \\ ${ }^{4}$ Assistant Professor (Contract), Dept. of Economics,LTK College, Lakhimpur, Assam, India- \\ 787001, E-mail: atanu.hazarika86@gmail.com
}

\begin{abstract}
Background-The outbreak of COVID-19 pandemic has affected the global economy from its starting. Indian economy is also affected by the pandemic and experienced a lot of economic damages. India has become the global hotspot of COVID-19 during the second wave of the pandemic and recorded the second-highest position in terms of positivity rate after China. The present study attempts to analyze the economic issues that emerged in the first and second waves of the pandemic in India.

Method/Approach-There is no econometric tools or analytical models used in the present study. This study attempts to evaluate the two research questions which are formed on the basis of some previous studies by various organizations and researchers. The research questions are as follow, First, what are the sectors those are primarily affected at the time of the first COVID-19 outbreak? Second, which economic issues and impacts emerged in the second wave of the pandemic?
\end{abstract}

Results/ Findings-From the study, it is found that the second wave of COVID-19 is not much affected by the Indian economy. At this time, no nationwide lockdown was announced by the Government. But so, it was much severe in the time of the first wave of COVID-19. Many sectors were affected by the pandemic like agriculture, MSMEs, Tourism, etc., and these resulted 
in substantial unemployment problems in the economy. The study is trying to analyze these problems and concluding it with a few policy recommendations for the economy of India.

Keywords: COVID-19, Indian Economy, First wave, Second Wave, Economic Revive

\section{Introduction}

The global economy is more interconnected in recent times. This interconnection is the leading cause of the rapid spread of the new and foremost human tragedy COVID-19 originated from Wuhan, China. The international labor organization (ILO) described the corona virus pandemic as 'the worst global crisis since world war II.' World Health Organization (WHO) declared this outbreak as COVID-19 in February, 2020. In March 2020, the COVID-19 pandemic was declared a global pandemic (WHO, 2020). A very high uncertainty surrounds the world economy. The health crisis that emerged due to COVID-19 is rapidly transmitted into an economic crisis after the declaration of lockdown in almost all the countries. COVID-19 poses a real threat to the global economy after the great depression in 2008. UNCTAD, the United Nation's Trade and Development Agency, already cautioned of depression of the international growth rate to below 2\% in 2020 (Bagchi et al.,2020). IMF, in its April 2020 'World Economic Outlook' reversed global economic growth forecast from $3.3 \%$ to $-3 \%$, an unusual downgrade of $6.3 \%$ within three months, and the cumulative GDP loss over the next year from COVID-19 could be around 9 trillion USD. As projections, there will also be an increase in unemployment, increasing a mark of more than 10\% at the end of 2020 (Buheji et al., 2020). This increase in unemployment will increase global poverty for the first time since 1990, creating a threat to UN Sustainable Development Goals (SDGs). Due to a fall in international economic activities, there will be a massive loss of international trade. As of March 25, 2020, global trade fell to over 4\% contracting for only the second time since the mid-1980s (Mohammed et al., 2021).

This global outbreak reaches more than 200 countries, and India is also one of them. As a developing country, India seems to be affected hard by this pandemic. The Indian economy has already been in a crisis phase before the occurrence of this pandemic. Demonetization in 2016 is one of the primary reasons for that crisis. After the emergence of COVID-19, people regarded it as a double hit to the Indian economy (Singh and Neog, 2020).Over the second half of 2019 and 
before the outbreak of COVID-19, India's economy was already sputtering with slow growth to 4.7\%. Further, unemployment was at a 45-year high, and the Indian industrial output for eight core sectors fell by 5.2\% last year (Mukharji, 2020). The outbreak of COVID-19 and subsequent lockdowns raises serious economic concern and havoc nationwide. The sudden nationwide lockdown in India greatly affected the social and economic life of the people.

The Indian economy was already struggling hard with the first wave of COVID-19 pandemic, and it becomes very severe when the economy is affected by the second wave of the pandemic. Various international organizations predicted that Indian economy will be facing a crisis of GDP and unemployment problem in upcoming years. According to India's World Bank Report unemployment rate in the year 2020, it was $7.11 \%$, which was below the world average of $7.99 \%$. But, it was the worst unemployment rate in India in 29 years. India's unemployment rate is projected at $20.13 \%$ for the fiscal year 2020-21(Barbate et al., 2021). A most emerging sector in India, MSME has provides around 100 million employment opportunities and contributes around $16.6 \%$ of GDP, the post-COVID experience of those employees will decline their incomes (Rakshit and Basistha, 2020). This article attempts to understand the economic effects of COVID-19 on the Indian Economy and analyze how the Indian Economy will revive from this pandemic situation. To study the effects of COVID-19, both the first wave and second wave are explained separately.

\section{First Wave of COVID-19 and Indian Economy}

In India, the first COVID-19 positive case was reported in Kerala on $27^{\text {th }}$ of January 2020 after that positivity rate was continuously increased as the day passes. To deal with this pandemic situation, the Indian Government declared 68 days lockdown of four-phased from $24^{\text {th }}$ March to $31^{\text {st }}$ May in the whole nation. The impact of this crisis may even be higher in emerging economies like India due to already slowing growth rates, poor health infrastructure, and a significant population living in extreme poverty. The spread of COVID-19 has exacerbated the Indian economy, which was already in peril, mainly due to slowing domestic demand and external factors like the US-China trade war (Sharma et al., 2020). While lockdown and social distancing result in productivity loss, on the one hand, they cause a sharp decline in demand for goods and services by the consumers in the market on the other, thus leading to a collapse in 
economic activity (Chaudhary et al., 2020). The IMF foresees that the impact on the economy of the coronavirus is many times greater than that of the Global Financial Crisis of 2008 (Nathan and Rodgers, 2020). The supply chain has broken due to the lockdown in every part of the country. Economic performance has been battered by the contraction of output on the supply side and employment contraction on the demand side (Nayyar, 2020). This pandemic has massively hit the supply and demand chain and caused trouble for manufacturers who have to fire some of their employees or delay their economic activities to prevent more loss (Kolahchi et al., 2021). The most affected areas are health, education, travel and tourism, agriculture, manufacturing, and the laborers, particularly those engaged in a low-paid job or the informal economy. Nearly $90 \%$ of the workforce in the informal sector has survived with no minimum wage or any social security (Singh and Neog, 2020). Economic activities of the whole nation have reached a near halt. Many workers and employees were lost their jobs because the producers and employers were unable to recover their costs. The states were incurring a huge economic cost for suspending the production process (Gollier and Gossner, 2020).

\subsection{Unemployment scenario}

Due to the sudden lockdown in the whole nation, the working class of the society was greatly affected during the pandemic. Many people, particularly daily wage earners or low-paid workers and migrant workers, become jobless or unemployed. The most significant impact of lockdown during COVID -19 pandemic was the disappearance of jobs, particularly in the case of migrant workers (Jha and Kumar, 2020). Employment declined in terms of both jobs and aggregate working hours (Mandal et al., 2020). This brought social insecurity and uncertainty to their economic lives due to the nationwide shutdown of economic activities. As per Centre for Monitoring Indian Economic (CMIE) estimates, in March 2020, the estimated number of employed persons in India was 396 million. It becomes 275 million by the end of April, which means more than 120 million jobs were lost. In the month of April-May 2020 unemployment rate was 23.5\% projected by (CMIE, 2020). According to National Statistical Office (NSO), during April-June 2020 India's GDP growth had contracted to $23.9 \%$. The country's unemployment rate during June, 2020 was a little bit impressive than the month of April-May 2020 and projected $8.5 \%$ by CMIE.

\subsection{Impacts on Travel and Tourism}


Tourism is a significant sector for generating income and employment in India. It contributes 9.2 percent of India's GDP in 2018 and creates 8.1 percent of its total employment. The tourism industry positively impacts the employment of countries, increasing foreign exchange earnings, promoting domestic industries, expanding international cooperation, and, most importantly, improving people's livelihoods and many other economic growth factors. India ranks eighth out of 184 countries in terms of tourism share in GDP with $247 \mathrm{bn}$. India's rank was 25th globally and $7^{\text {th }}$ in Asia concerning international tourist arrivals in 2018. The share of tourism in total employment is $12.13 \%$ in $2017-2018$ and rises to $12.75 \%$ in $2018-2019$ (India Tourism Statistics, 2019). India's position in the travel and Tourism Competitive Index (TTCI) of the world economic forum is $40^{\text {th }}$ position in 2017 , and currently, India has uplifted to 34th position in 2019. This sector's direct and indirect employment also rises to 5.56-7.19 percent in 2018-2019. The nationwide lockdown will restrict both international and domestic tourist movement. "The Indian tourism and hospitality industry is staring at a potential job loss of around 38 million, which is $70 \%$ of the total workforce," due to corona virus (Shetty, 2021). There is a $66.4 \%$ decline in overseas tourists' arrivals in India in March 2020 compared to last year. There is a fall in foreign tourists' arrival rate by $68 \%$ from February to March 2020 and hence a fall in foreign exchange earnings (FEE) by $66.32 \%$, which has a significant impact on the economy (Jaipuria et al., 2021).

\subsection{Impacts on Agriculture Sector}

Agriculture is the primary source of livelihood for about $58 \%$ of India's population. Indian agriculture sector was performing pretty well before the COVID-19 pandemic. According to research conducted by National Institute of Agricultural Economics and Policy Research under ICAR (Indian council for Agricultural Research) in October, 2020, Annual growth has been ranging between $3.5 \%$ and $5 \%$ during the last five years and the growth has broad-based itself, in terms of both production and geographical coverage. The immediate impact of lockdown in agriculture was in the form of disruption of harvesting and marketing of crops. COVID-19 lockdown in India has primarily impacted farmers' ability to sell their produce and livestock products and decreased daily wages (Jaacks, L. M. et al., 2020). It has disrupted the production process and thereby broken the supply chain, which is reflected through the changes

in food prices. However, the disruption in the supply chain was tried to make functional by using digital technologies. The COVID-19 crisis has shown how digital technologies can help make 
supply chains function better and more efficiently (Kumar et al., 2020). The National Agriculture Market (e-NAM) has allowed the farmers to connect with more significant agricultural markets. There have been an increased number of registered traders on this digital platform. The demand side shock arises because of the people's low purchasing power, particularly of the poor class of society. As a result, household expenditure has declined by 27 percent in real terms, and investment has reduced by 47 percent in the first quarter of the financial year 2020-21 (Niap, 2020). Therefore, the Indian Government has raised expenditure by 16 percent to deal with this situation. Despite all the adverse effects, due to some government measures are taken during that time, the agriculture sector registered positive growth post-pandemic (3.4\% FY 2020-21 Quarter 1: April to June) but less than its immediate past quarter growth (5.9\% FY 2019-20 Quarter 4: January to March) witnessing a decline by 2.5\% point due to the impact of COVID-19 (Cariappa et al., 2021).

\subsection{Impacts on MSMEs}

MSME (Micro, Small, and Medium Enterprise) sector has emerged as a highly vibrant and income-generating sector with low capital cost in India over the last five decades. The sector is currently employing over 110 million people, which is $40 \%$ of India's workforce. The MSME sector contributes to $29.7 \%$ of Indian GDP including $6.11 \%$ of manufacturing sector GDP and around $24.63 \%$ of service sector GDP. MSMEs are the source of $33.4 \%$ of the total manufacturing output and $45 \%$ of the overall exports in India (Rakshit and Paul, 2020). MSME sector has badly affected during COVID-19 lockdown due to massive labor migration, disruption in production, and lack of cash flow. Due to the unavailability of cash, the MSMEs are starting pay cuts of workers, resulting in job losses and creating unemployment problems. All India Manufacturers' Association (AIMO) carried out a study among 5000 MSMEs and reported that about $71 \%$ of MSMEs could not pay remuneration to their employees in March 2020. It was estimated that $25 \%$ of firms comprising the MSME sector in India were on the verge of collapsing if the Indian Government extended the tenure of nationwide lockdown for more than eight weeks starting from April 2020. Nearly 50\% of business units under the MSME sector in India suffered a loss equivalent to 20-25\% during the COVID-19 pandemic situation (Roy et al., 2020).It was also predicted the manufacturing sector might shrink from 5.5 to 20 percent, exports from 13.7 to 20.8 percent, imports from 17.3 to 25 percent in 2020 over the previous year (Shahoo and Ashwani, 2020).

6|P a g e 


\section{Second Wave of COVID-19 and Indian Economy}

India has become a global hotspot of COVID-19 pandemic during the second wave, with daily new cases touches 4.12 million in May 2021. The number of positive cases crossed 2.9 crores in the first week of June, 2021. After USA, India has become the second-highest country in the world based on COVID-19 positivity cases. As seen by the situation of India, many countries have announced to ban Indian flights and restricted travel from India. For this reason, many Indians are affected by their international transactions.

During the second wave of COVID-19 pandemic, India has provided quite different guidelines as provided in the first COVID outbreak. At this time, no nation-wise lockdown is announced. Some states have announced partial lockdown by providing their SOP for their citizens. To some extent, some states like Delhi, Maharashtra, etc., have notified complete lockdown for few days. But during this period death rate of human lives keep growing faster than the first wave of COVID-19 pandemic. The death rate has crossed 3.51 lakhs in the first week of June 2021. The highest death rate was recorded in May, 2021. To reduce the infections among citizens, both central and state governments have done works cooperatively. Both governments have given more importance to the vaccination process. So that, in the first week of June 2021, around 23 crore people are vaccinated in India.

The economy of India already affected by the first wave of the pandemic, and again it will be collapsed just recovery from the first COVID-19 outbreak. But, According to the central bank of the country RBI; the second wave of COVID-19 will be less affected than the first wave (RBI, 2020). During the second wave of the pandemic rising unemployment problem and reduction of employment opportunities has emerged as the most significant economic issue. The Service sector like tourism and hospitality, which had just started recovering from the crisis of COVID-19 outbreak the second wave of the pandemic, again hit it. MSME sector, the secondhighest employment generated sector after agriculture of the country, affected very much and would require financial support. So that the country's GDP in upcoming days will be predicted loss, according to CRISIL, India's GDP may be slipped to $8.2 \%$ in the financial year 2021-22 if the second wave of COVID-19 pandemic peaks at the end of June 2021. But, in the crisis of the second wave of the pandemic RBI has published a report in May 2021 and projected a 10.5\% growth rate for Indian economy for the financial year 2021-22. It was predicted by National Institution predicted it for Transforming India (NITI) aayog, agriculture sector of the country 
will not be affected this time as involved in the first COVID-19 outbreak. Because this time, no nationwide lockdown is announced, and many states of the country provide only a few restrictions for their agricultural activities.

\subsection{A situation of Employment and Consumer demand}

According to CMIE, the Unemployment rate increased to 7.97\% in April-May 2021 from 6.5\% in March 2021, and around seven million jobs lost in April 2021. During this time, the informal sector, like a small business person and poorer sections of the society, are badly affected by the pandemic. Because many of them already been pushed below the poverty line during the first wave of the pandemic. During the second wave of COVID-19, consumer demand is reduced due to higher healthcare costs. Price of the edible oil in the second wave of the pandemic increases and the demand for other consumer goods also sharp declines. RBI has projected the CPI inflation of India at an average 5\% in fourth quarter of 2020-21. It also projected the CPI inflation $5.2 \%$ in first quarter and second quarter of $2021-22,4.4 \%$ in third quarter and $5.1 \%$ in fourth quarter.

\section{Can India Revive? With a few policy recommendations}

The revival of Indian economy may be a long-term process. The long term will be depending on the mode of recovery that the economy would be able to adopt (Barbate et al., 2021). The second wave of the pandemic may be a cause of long-term process of economic recovery. In this concern, government investment will play an essential role in boosting the economy from the crisis of demand chain disruption and supply chains settlements. The disruption of supply chains due to the pandemic means that India should explore opportunities in new markets in Africa and Southeast Asia, which are also likely to be more receptive to nonChinese trading partners (Shingal, 2020). Higher investment will also create new job opportunities for the job seekers and the persons who have lost their jobs due to the pandemic. During the United States' 2009 great depression declaration of recovery packages, investment in public transport and clean energy was created more employment than traditional investments (Srivastava, 2020).

To see the country's economic crisis during the first wave of the COVID-19 pandemic, India announced a package under the scheme 'Atmanirbhar Bharat' (Self-Reliance India) of Rs 20 trillion for the revival of the economy. World Bank had also approved 2.75 billion USD 
emergency lending for India to support the response of COVID-19. It was disbursed 2.25 billion USD by December 2020. These economic packages may be a pivotal instrument to revive the economy from the crisis in the upcoming days. To give more concentration to the MSMEs government of India also changed the definition of MSMEs during the COVID-19 outbreak by increasing the investment pattern. In this concern, government needs to come forward with innovative long-term tax concession schemes on the value of sub-contracts given to the MSME sector (Raychaudhuri, 2020). It will be helpful to MSMEs of the country in the upcoming years. Government of India provides attention to the vulnerable sections of the country through Pradhan Mantri Garib Kalyan Yojana (PMGKY) also provides support for Mahatma Gandhi National Rural Employment Guarantee Act (MGNREGA), but it is limited and too little (Jha and Kumar, 2020). Under PMGKY, Government has contributed 12\% employer's share and 12\% percent employee's share through Employees Provident Fund (EPF) for March to August 2020. If the government support is increased through these programs, it will help workers and employees directly.

The recovery of the economy will also depend on the healthcare investment of the

country because solid and sustainable containment measures in the health sector like testing of COVID-19 and vaccination may raise the confidence of the citizens, which will be helpful to the economy for quicker recovery. The agriculture sector of the Indian economy can also be used as a revival alternative from the present crisis. About 70 percent of the total population of India is engaged in the agriculture sector. If agriculture can be converted to multiple cropping systems, it will give away to put forward the economy from the crisis that happened in the COVID-19 pandemic. There is a possibility of MGNREGA; if it can be converted more demand centric rather than supply centric. Higher employment generation via MGNREGA will be a solution to prevent the income and demand crisis among the citizens.

\section{Conclusion}

This article tries to assess the Indian economy's economic issues during the first and second waves of COVID-19 and analyze how India can get revived from this pandemic. The study found that Indian economy was hit hard by this pandemic as it was already in a crisis phase with the slowdown in economic activities. The economic impact of the first wave of COVID-19 was very severe compared to the second wave of COVID-19. Almost all the sectors, including 
MSMEs, travel and tourism, unemployment, and migrant laborers were deeply affected by this pandemic situation. Agriculture was the only sector that performed positive signs during the pandemic. To cope with these adverse economic effects, the Government of India has been doing well by taking various policy measures. Apart from this, the economy needs proper vaccination to get revived from the long-term effects of COVID-19. To build up the way of quicker recovery of the economy government policies and mode of the economic situation in upcoming days will be crucial. 
Funding Source: For the completion of the study there are no any funding sources.

\section{Acknowledgement: NIL}

Authors Contribution: The article is mainly based on literature survey. Firstly all the authors selected the areas of Indian economy those who mostly affected by the COVID-19 pandemic. Secondly, the areas were divided among the authors to survey the literatures of their respective fields. At last we have included all the surveys in single platform and finalize after a brief review process individually. In this article, all the authors have equal contribution to complete it.

Conflict of interest: There are no conflicts of interest among the authors.

\section{References:}

Abella, Manolo I and Sasikumar, S. K. 2020. Estimating Earnings Losses of Migrant Workers Due to COVID-19. The Indian Journal of Labour Economics 63: 939-921.

Bagchi Bhaskar, Chatterjee Susmita, Ghosh Raktim and Dandapat Dhrubaranjan. 2020. Impact of COVID-19 on Global Economy. Springer Briefs in Economics, in: Coronavirus Outbreak and the Great Lockdown, chapter 3, pp. 26-15.

Barbate Vikas, Gade Rajesh N. and Raibagkar Shirish S. 2021. COVID-19 and Its Impact on the Indian Economy. Vision 25: 35-23.

Buheji, Mohamed. Cunha, Katiane da Costa. Beka, Godfred. Mavrić, Bartola. de Souza, Yuri Leandro do Carmo. Simone Souza da Costa Silva, Mohammed Hanafi, and ChetiaYeinTulika.(2020),“The Extent of COVID-19 Pandemic Socio-Economic Impact on Global Poverty. A Global Integrative Multidisciplinary Review',American Journal of Economics,Vol. 10 No.4, pp. 213-224. DOI: 10.5923/j.economics.20201004.02. 
Business Standard. available online: https://www.business-standard.com/article/economypolicy/govt-assessing-economic-impact-of-second-covid-wave-for-possible-stimulus121052501320_1.html\#: :text=Govt\%20assessing\%20economic\%20impact\%20of\%20s econd $\% 20$ Covid $\% 20$ wave $\% 20$ for $\% 20$ possible $\% 20$ stimulus,-

Press \%20Trust $\% 20$ of\&text $=$ The $\% 20$ government $\% 20$ might $\% 20$ tweak\%20the,per $\% 20$ ce nt\%20of\%20the\%20GDP. (Accessed on July 27, 2021).

Business Today. available online : https://www.businesstoday.in/latest/economypolitics/story/covid-19-second-wave-indias-gdp-growth-can-slip-to-82-in-fy22-sayscrisil-295414-2021-05-10 (Accessed on june 21, 2021)

Business Today. available online :https://www.businesstoday.in/latest/economypolitics/story/covid-19-second-wave-impact-on-indian-economy-not-as-bad-as-firstwave-says-rbi-297117-2021-05-27 (Accessed on June 28, 2021)

Business World. available online : http://www.businessworld.in/article/RBI-Pegs-RetailInflation-At-4-4-5-2-For-This-Fiscal-Says-Some-Underlying-Constituents-TestingUpper-Tolerance-Level/07-04-2021-385842/ (Accessed on july 23, 2021).

Cariappa, AG Adeeth ,Acharya, Kamlesh Kumar., Adhav, Chaitanya Ashok., Sendhil, R., and Ramasundaram, P. 2020. Impact of COVID-19 on the Indian agricultural system: A 10point strategy for post-pandemic recovery. Outlook on Agriculture 50: 33-26.

Chaudhary Monika, Sodani, P. R. and Das Shankar. 2020. Effect of COVID-19 on Economy in India: Some Reflections for Policy and Programme. Journal of Health Management 22: 180-169.

CMIE. 2020. "The jobs bloodbath of April 2020" available online: https://unemploymentinindia.cmie.com/ (Accessed on 25 July 2021).

Gollier, C., and Gossner, O. 2020. "Group testing against covid-19. Covid Economics”, Working Papers 2020-02, Center for Research in Economics and Statistics, available at: https://ideas.repec.org/p/crs/wpaper/2020-02.html. (Accessed on July 27, 2021)

ICAR .2020. “Annual Report 2020”, availble at: https://icar.org.in/sites/default/files/ICAR-AR2020-English.pdf (Accessed on August 02, 2021).

India Tourism Statistics. 2019. "India Tourism statistics 2019” Govt. of india, Available at: https://tourism.gov.in/sites/default/files/202004/India\%20Tourism\%20Statistics\%20201 9.pdf. (Accessed on June 28, 2021). 
ILO. 2020. "COVID-19 causes devastating losses in working hours and employment", available at: https://www.ilo.org/global/about-the-ilo/newsroom/news/WCMS_740893/lang-en/index.htm. (Accessed on july 15, 2021).

Jaacks, Lindsay M., Veluguri, Divya, Serupally, Rajesh, Roy, Aditi, Prabhakaran, Poornima., and Ramanjaneyulu, GV. 2021. Impact of the COVID-19 pandemic on agricultural production, livelihoods, and food security in India: baseline results of a phone survey. Food Security. Available at: https://link.springer.com/content/pdf/10.1007/s12571-02101164-w.pdf. (Accessed on july 15, 2021).

JaipuriaSanjita ,ParidaRatri\& Ray Pritee. 2021. The impact of COVID-19 on tourism sector in India. Tourism Recreation Research 46: 260-245.

Jha Praveen and Kumar Manish. 2020. Labour in India and the COVID-19 Pandemic. The Indian Economic Journal 68: 437- 417.

KolahchiZahra, DomenicoManlio De, UddinLucina Q,Cauda Valentina, Grossmann Igor ,Lacasa Lucas , GranciniGiulia , MahmoudiMorteza,Rezaei Nima. 2021. COVID-19 and Its Global Economic Impact, Coronavirus Disease - COVID-19. Edited by Rezaei N. Advances in Experimental Medicine and Biology, Vol. 1318. Springer, Cham.

Kumar, A., Padhee, A.K. \& Kumar, S. 2020. How Indian agriculture should change after COVID-19. Food Sec 12: 840-837.

Mandal, Kajal Kumar, Alam, Snehashis.Ranjan, Avinash. Dharanirajan, K. KumariPammy. 2020. A Review of India's Response to Covid-19 Outbreak and the Impact of Lockdown on the Indina Economy. Journal of Critical Reviews 7: 408-402.

Mohammed T. Ibn, Mustapha, K.B., Godsell J., Adamu Z., Babatunde K.A., Akintade D.D., Acquaye A., Fujii H., Ndiaye M.M., Yamoah F.A., and Koh S.C.L. 2021. A critical analysis of the impacts of COVID-19 on the global economy and ecosystems and opportunities for circular economy strategies. Resources, Conservation \& Recycling, 164: $22-1$.

Mukharji A. 2020. Coronavirus: India's bailout may not be enough to save economy", $B B C$ News, 3 April, available online: https:/www.bbc.com/news/world-asia-india-52117704 (Accessed on May 22, 2021).

Nathan, Dev and Rodgers Gerry. 2020. Introduction: the Critical Connection between COVID-19 and Employment. The Indian Journal of Labour Economics 63: 9-1. 
Nayyar, Deepak. 2020. Lives, Livelihoods and the Economy: India in Pandemic Times. The Indian Journal of Labour Economics 63: 59-53.

Niap. 2020. "Covid-19 Lockdown and Indian Agriculture: Options To Reduce The Impact", Working Paper, NIAP, New Delhi.

Rakshit B, Basistha D.2020. Can India stay immune enough to combat COVID-19 pandemic? An economic query. Journal of Public Affairs 20: 7-1.

Rakshit D. and Paul A. 2020. Impact of Covid-19 on Sectors of Indian Economy and Business Survival Strategies. International Journal of Engineering and Management Research 10: $55-51$.

Raychaudhuri A.2020. COVID-19 Pandemic Crisis and the Way Forward for India. COVID-19: Challenges for the Indian Economy - Trade and Foreign Policy Effects; 2020, published by Epic India, VanijyaBhawan, 1st Floor International Trade Facilitation Centre.

RBI. 2021. "RBI Bulletin- May 2021", available online: https://www.rbi.org.in/Scripts/BS_PressReleaseDisplay.aspx?prid=51588. (Accessed on July 04, 2021)

Roy Arundhati, Patnaik B.C.M. and Satpathy I.2020. Impact of Covid-19 crisis on Indian MSME sector: A study on remedial measures. Eurasian Chemical. Communications 2: 1000991.

Sahoo P., and Ashwani.2020. COVID-19 and Indian Economy: Impact on Growth, Manufacturing, Trade and MSME Sector. Global Business Review 22: 1183-1159.

Sharma, Gagan Deep. Talan, Gaurav. Jain, Mansi. 2020. Policy response to the economic challenge from COVID-19 in India: A qualitative enquiry. Journal of Public Affairs 20: 16-1

Shetty P. 2021. The Impact of COVID-19 in the Indian Tourism and Hospitality Industry: Brief Report. Journal of Tourism \& Hospitality. 10: 7-1.

Shingal A. 2020. Responding to the COVID-19 Crisis: Policy Priorities for India. COVID-19 Challenges for the Indian Economy: Trade and Foreign Policy Effects. published by Epic India, VanijyaBhawan, 1st Floor International Trade Facilitation Centre .

Singh M. K. and Neog Y.2020. Contagion effect of COVID-19 outbreak: Another recipe for disaster on Indian economy. Journal of Public Affairs 20: 8-1. 
Srivastava A. 2020. After COVID-19, 5 Ways India Can Pursue a Sustainable and Resilient Recovery. available online :https://www.wri.org/insights/after-covid-19-5-ways-indiacan-pursue-sustainable-and-resilient-recovery (Accessed on julu 06, 2021).

The Hindu. available at: https://www.thehindu.com/business/most-msmes-skipmarchsalaryaimo/article31273979.ece. (Accessed on July 24, 2021).

The Wire. Available online :https://thewire.in/economy/as-covid-19-second-wave-wreaks-havocindia-lost-over-7-million-jobs-in-april-cmie. (Accessed on july 12, 2021)

WHO. 2020. "Listings of WHO's response to COVID-19", available online: https://www.who.int/news/item/29-06-2020-covidtimeline (Accessed on August 01, 2021) 